No. Issue: $10 \mid$ Research Articles |pp. $69-79$

\title{
The Effect of Non-Medical Waste Management in Hospitals on the Comfort and Satisfaction of Patients Towards Green Hospital
}

\author{
Edy Suwasono ${ }^{1, *}$ \\ 1 Department of Management, Faculty of Economics, Islamic University of Kadiri; \\ * Correspondence: suwasono_edy@yahoo.co.id; Tel.: +62-812-3176-278
}

Received: 16 August 2019; Accepted: 25 August 2019; Published: 30 September 2019

\begin{abstract}
The management of environmentally friendly non-medical hospital waste towards Green Hospital is the needs of the community of health service users. The purpose of this study is to determine the effect of non-medical waste management in hospitals on patient comfort and satisfaction towards green hospitals. The purpose of the study entitled the effect of non-medical waste management in hospitals on patient comfort and satisfaction towards green hospitals. This research was conducted at the Regional General Hospital (RSUD) Pare, Kediri Regency. The target population in this study were inpatients who underwent treatment at Pare Regional Hospital Kediri in April to August 2012. Data in this study consisted of primary data and secondary data. Primary data collection was carried out through distribution of questionnaires to hospital residents and in-depth interviews with hospital management. Respondents in this study were 137 people. Analysis of the data used in this study was to determine the effect of nonmedical waste management in hospitals on patient comfort and satisfaction towards green hospitals using two approaches namely qualitative and quantitative analysis. The model used in this study is the model of causality or causality in the form of structural equations (Structural Equation Model / SEM). Research results Management of non-medical solid waste and hospital garden vegetation has not been carried out optimally. Improved management of non-medical waste will increase patient comfort and satisfaction. The high level of comfort in the patient will increase patient satisfaction. Good management of non-medical waste does not directly affect satisfaction but through patient comfort and Vegitation in the hospital garden influences patient comfort and satisfaction.
\end{abstract}

Keywords: Environment, Green Hospital, SEM (Structural Equation Modeling), Waste Management

\section{Introduction}

Global warming is an important issue throughout the world. Earth's rising temperatures make the earth hotter and pose new threats, for example the high frequency of rain, storms, hurricanes, floods and forest fires. The use of energy for daily use contributes to the greenhouse effect, which also has an impact on global warming.

The existence of hospitals in a single ecosystem in the midst of the issue of the impact of climate change and global warming and environmental degradation is deemed necessary to be responsible for the sustainability of environmental quality and the utilization of natural resources. Hospital buildings need to be designed and designed to accommodate the efficient use of natural potential, hospital-based natural resources and the environment such as clean water, energy, paper and other materials that are daily needs of hospital operations. Their use also needs to be based on the principle of eco-efficiency it means that efficiency improvement comes from improving environmental performance or production processes that minimize the use of raw materials, while hospital side products such as liquid, solid and gas waste need to be processed so that the target is not only to meet the quality standards of waste, but also to meet the reduce, reuse, recycle and 
recovery. In principle, the hospital model in the future needs to be managed properly by always considering health, economic, ecological and social aspects so that the principle of fulfilling the concept of sustainable development in the health sector will be fulfilled, and the hospital can play an active role in reducing the impact of climate change and reducing carbon footprints it generates, as is the policy of the World Health Organization (WHO) contained in Healthy Hospitals, healthy planet, healthy people (Addressing Climate Change in Health Care Settings).

Comfort and comfort are one's comprehensive assessment of the environment. Humans judge their environment based on stimulation that enters themselves through the six senses through the nerves and digested by the brain to be assessed. In this case, it involves not only physical biological problems but also feelings. Sound, light, smell, temperature and other stimuli are captured at once, then processed by the brain. Then the brain will provide a relative assessment of whether the condition is comfortable or not. Discomfort in one factor can be covered by other factors (Satwiko, 2009).

Comfortable according to the Big Indonesian Dictionary, is fresh; healthy, while comfort is a comfortable state; freshness; coolness. The convenience of a building is regulated in RI Law No. 28 of 2002 dated 16 December 2002, Part Four Article 26 paragraph 1 to paragraph 7. RI Law No. 28 of 2002 concerning Requirements for Building Constraints, Paragraph 4 article 26, namely paragraph (1) Requirements for the comfort of buildings as referred to in article 16 paragraph (1) to paragraph (6) include the comfort of space, and relationships between spaces, air conditions in space, views and vibration levels and noise levels. Therefore a study entitled the effect of nonmedical waste management in hospitals on patient comfort and satisfaction towards green hospitals.

\section{Research Methods}

This study uses two analytical approaches, namely quantitative and qualitative analysis. Malhotra (2004) states that a population is a combination of all elements that have a set of similar characteristics that include the universe. In the context of research with quantitative methods, the study population was all patients of Pare Regional Hospital, Kediri Regency. Information about the total number of patients in the Kediri district hospital is unknown.

This research was conducted at the Regional General Hospital (RSUD) Pare, Kediri Regency. The basis for determining the sample of this hospital is the method of random sampling or random from the population of the entire Regional General Hospital in a region ex-residency of Kediri. According to Arikunto (2006: 133) sample research can be done if the subjects in the population are truly homogeneous. The technique of determining random samples / random samples is by selecting one sample from the sampling frame after each population element has been coded (numbers or symbols).

The target population is a collection or element that has the information sought by researchers whose inference about it will be made (Malhotra, 2004). The target population in this study were inpatients who underwent treatment at Pare Regional Hospital Kediri in April to August 2012. Data in this study consisted of primary data and secondary data. Primary data collection was carried out through distribution of questionnaires to hospital residents and in-depth interviews with hospital management. Respondents in this study were 137 people. Primary data obtained directly from the results of interviews conducted with patients. Primary data intended in this study include hospital non-medical solid waste management, comfort level and patient satisfaction.

Secondary data in this study in the form of data that is available and has been processed by the District Hospital of Pare Kediri, including: facilities available in hospitals, administrative rooms, treatment room data, data on the state of employees both administrative staff, doctors and nurses, as well as hospital reports on the type of work, length of stay and patient education level.

Analysis of the data used in this study was to determine the effect of non-medical waste management in hospitals on patient comfort and satisfaction towards green hospitals using two approaches namely qualitative and quantitative analysis. Descriptive qualitative used quantitative 
tools to help score. Assessment using a Likert Scale with a Likert scale of 5 (five) research scores ie $1=$ strongly disagree, $2=$ disagree, $3=$ neutral, $4=$ agree, $5=$ strongly agree. The model used in this study is the model of causality or causality in the form of structural equations (Structural Equation Model / SEM). Data processing to find SEM equations, using AMOS 16 software.

\section{Results and Discussion}

The use of Structural Equation Modeling (SEM) in behavioral studies is increasingly popular as a statistical method for testing various relationships in a model. This method has a better function compared to other multivariate techniques such as multiple regression analysis, path analysis and factor analysis (Maruyama and McGarvey, 1980). SEM has been used successfully in analyzing problems in social science studies (Joreskog and Sorbom, 1982). To analyze, evaluate the validity and causality between constructs of this model, AMOS 201 software is used (Arbukle \& Wothke, 1999).

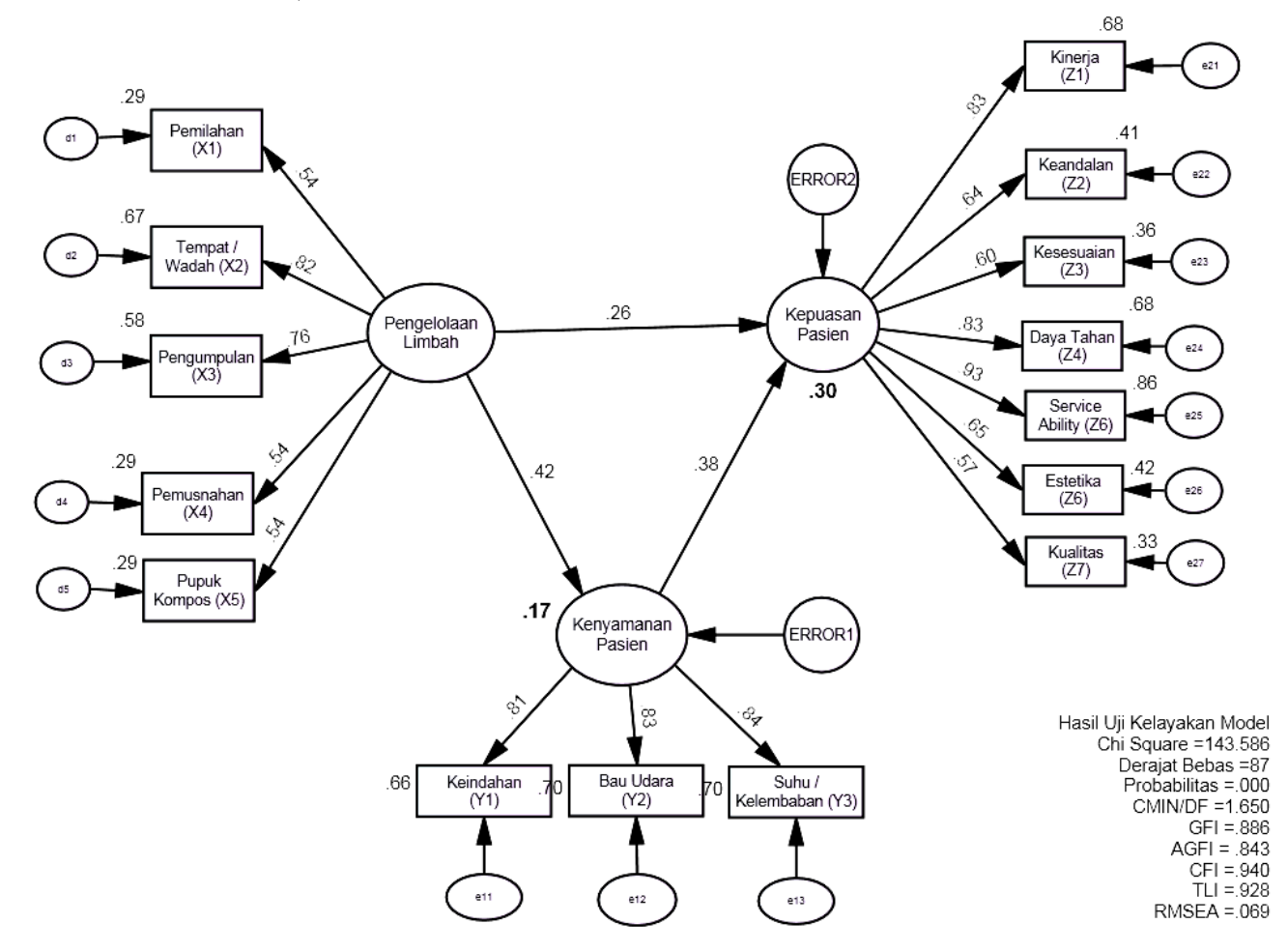

Fig. 1. Structural Model Results

A summary of the results obtained in the analysis and recommended values for measuring the feasibility of the model. The results of the model feasibility test on the structural model show that the absolute fit section consisting of chi square values, GFI and RMSEA shows that there are no components that meet the requirements. The GFI value of 0.886 is marginal because it has a value between 0.80-0.90, while the RMSEA $=0.069$ is good because it is under 0.08 .

The GFI value has a similar understanding of R2 in the regression analysis that is the calculation of the weighted proportion of the variance in the sample covariance matrix which is explained by the estimated population covariance matrix (Bentler, 1993). So the GFI value of 0.886 means that $88.6 \%$ of the population covariance matrix can be explained by the sample covariance matrix. The RMSEA value is a model indicator that measures the deviation of the parameter values of a model with its population covariance matrix (Browne and Cudek, 1993). The RMSEA value of 0.069 meets the recommended recommendation criteria which is below 0.08 , so the feasibility of the model based on the RMSEA is good. The results of the test model 
with chi-square produce a value of 143,586 with a probability of 0,000 . These results explain that the variance-covariance matrix of empirical data differs from the proposed model (prob <0.05). So that on the absolute fit component, this structural model is unacceptable.

The feasibility of the model in the parsimonious fit section consists of CMIN / DF and AGFI components. The AGFI value has the same meaning as GFI but the existing value has adjusted to the influence of the degree of freedom in a model. The recommended AGFI value is at least 0.80, and in this analysis the resulting AGFI is 0.843 . The AGFI value is marginal because it is between 0.80-0.90. While the CMIN/DF value of 1,650 is in good status because it is less than 2, so that the structural model of the parsimonious fit component is unacceptable.

The model eligibility index in the incremental fit section consists of CFI and TLI values. The Tucker Lewis Index (TLI) value recommends at least 0.95 (Hair et al., 2010) and the results from the calculation of the TLI model have only reached 0.928 . Whereas the feasibility index with the Comparative Fit Index (CFI) recommends a value of at least 0.95 (Hair et al., 2010) and the calculation results have only reached 0.940 . So that the incremental fit component of this structural model is unacceptable.

The results of the analysis of the three elements of the model feasibility review conclude that this structural model has an unacceptable feasibility. The initial model will often be faced with unsatisfactory results, so that the model will be respesified or evaluated. The results of the evaluation of this model are expected to be able to improve the suitability of the model under study. This is commonly done by researchers, although some people are criticized and call it a "data-driven statistical conclusion" (Chin and Todd, 1995). As if this leads to actions to revise the "what is the data" model. There are two approaches in model respesification: first, 'trimming theory' (Dillon, 1984 and Pedhazur, 1982) which attempts to answer which parameters will be removed in order to improve the suitability of the model. The second is 'theory building' which adds parameters to improve the suitability of the model. The second way is commonly known as modification indeces (MI). One recommendation from MI is the correlation between error indicators. Reddy (1992) suggests that the calculation results of MI which are of great value and rational for relations between indicators should not be ignored, although in theory the relationship of these indicators is difficult to find but if there is an empirical approach, the addition of these parameters can be done. Evaluation is done by adding error correlations between exogenous or exogenous contracts in accordance with the results of large modification indeces (MI) calculations.

The results of the study prove that the improvement of non-medical waste management as measured in the dimensions of sorting, place / container, collection, transportation, culling and making compost can increase patient comfort as measured in the dimensions of beauty, air odor and air temperature directly. This shows that, if non-medical waste management is carried out as a fixed procedure (procedure) regarding the management of non-medical waste provided by the Pare Regional Hospital of Kediri Regency, patients and visitors will feel comfortable.

Actually the management of non-medical waste in Pare Regional Hospital of Kediri Regency has used Kep. Minister of Health RI No.1204/Menkes/SK/X/2004 concerning Hospital Environmental Health Requirements. However, the handling has not been evaluated optimally. An evaluation needs to be done in order to review the results of the application of the non-medical waste handling regulations. This was also conveyed by Atik (2011), who explained that evaluation of waste management is a management that needs to be done to create the effectiveness and efficiency of waste management. Akter's (1999) research on hospital waste in the city of Dhaka, Bangladesh shows that both clinical waste and other types of waste generated by hospitals will affect the surrounding population and the environment.

The development of health science nowadays has given rise to a new understanding of environmental health. According to WHO, in 2007 one in four diseases experienced by the world population was caused by the influence of exposure to environmental factors (Wilburn, 2007). The health sector industry also contributes in producing $>2.4$ billion tons of waste per year and is one of the biggest energy consumers in many regions (Sattler and Hall, 2007). Waste and hospital energy consumption affect environmental health and consequently also affect the health of every 
human being in the environment. Meanwhile, the hospital which is responsible for treating patients from illness, must also be responsible for protecting the environment, improving the health of clients, staff and the environment itself (Harris et al., 2009).

Waste management in Pare Regional Hospital of Kediri Regency must receive serious attention, because waste can pollute the environment of the population around the hospital and can cause health problems. This is because in hospital waste can contain various microorganisms that cause disease in humans including typoid fever, dysentery and hepatetics so that waste must be treated before being discharged into the environment (BAPPEDAL, 1999).

Management, (Echols, 1996) namely achieving organizational goals effectively and efficiently through planning, organization, direction and control of organizational resources (Richard L. Daft). To know more clearly about the dimensions of non-medical solid waste management in Pare Regional Hospital, Kediri Regency is as follows,

a. Dimension of non-medical solid waste sorting at Pare Regional Hospital, Kediri Regency,

Non-medical Solid Waste sorting is done by sorting waste that can be utilized with waste that cannot be reused including wet waste and dry waste. Officials of Pare Regional Hospital of Kediri Regency who specifically handle this solid waste amounted to 30 (thirty) personnel, divided into 3 (three) shifts, namely workers from morning to afternoon, afternoon to night and night to morning.

Waste in Pare Regional Hospital of Kediri Regency is separated by containers / containers specifically for wet and dry waste, besides in medical service places there are containers / containers for medical waste.

Waste separation (Sundana, 2000): Waste must be separated from its source. All high-risk waste should be clearly labeled, it is necessary to use plastic bags in different colors, which indicate where the plastic must be transported for incineration or disposal. In some countries, plastic bags are quite expensive so that you can use leak-proof paper bags instead (locally made so they can be easily obtained). These paper bags can be affixed with colored strips, then placed in color-coded barrels on wards and other units.

According to the Decree of the Minister of Health of the Republic of Indonesia Number 1204 / Menkes / SK / X / 2004 regarding the Environmental Health Requirements of Hospitals, Sorting and Reserving: 1) Reservoirs of non-medical solid waste must be separated from solid medical waste and collected in black plastic bags. 2) Places of worship; Every solid waste disposal site must be covered with a black plastic bag as a solid waste wrapper with a white "domestic" symbol. If the density of flies around the waste site exceeds 2 (two) tails per-block grill, control is needed.

b. Dimensions of container / non-medical solid waste container in Pare Regional Hospital, Kediri Regency,

Container/place/container of Pare Regional Hospital of Kediri Regency, totaling 124 units with details of 62 wet waste containers and 62 dry waste containers. In accordance with the provisions, the Non-Medical Solid Waste Reservoir must be made of a material that is strong enough, lightweight, rust resistant, waterproof, and has a surface that is easy to clean on the inside, for example fiberglass. Has a lid that is easy to open and close without getting dirty in your hands. There is at least 1 (one) piece for each room or as needed. Waste must not be left in its container for more than $3 \times 24$ hours or if $2 / 3$ of the bag has been filled with waste, it must be transported so that it does not become a disease vector or animal pest.

c. Dimensions of waste collection and transportation in Pare Regional Hospital, Kediri Regency,

In collecting non-medical solid waste in Pare Regional Hospital, Kediri Regency, bags with black color must be taken if it contains $2 / 3$ parts. Then the upper part is tied and given a clear label, the bag must be transported by holding its neck, so that if carried swinging away from the body, and placed next to the very end of the room to be collected. Sanitary of Pare Regional Hospital of Kediri Regency, non-medical solid waste collectors must ensure bags of the same color have been put together and sent to the 
appropriate place, bags must be stored in boxes that are resistant to fleas and destructive animals before being transported to their disposal sites.

Waste collection in Pare Regional Hospital of Kediri Regency is carried out, where the bags with color-coded can only be transported when they have been closed, the bags are held on their necks, officers must wear protective clothing, for example by wearing strong gloves and overal clothing, when transport the bag, if there is contamination outside the bag, a new, clean bag is needed to wrap the new, dirty bag in it (double bagging). Officers are required to report if they find sharp objects that can injure them in the wrong bag. No one can put his hand in a waste bag.

Collection of non-medical solid waste, if at the temporary collection point the level of flies density of more than 20 per-block grill or rat is seen during the day, must be controlled, under normal circumstances must be controlled insects and other disturbing animals at least 1 (one) once a month.

Temporary Non-Medical Solid Waste Shelter in Pare Regional Hospital of Kediri Regency, separated between waste that can be utilized and waste that cannot be reused. The place is not a source of odor, and flies in the surrounding environment are equipped with channels for leachate. Temporary solid waste shelters must be waterproof, closed and always in a closed condition when not being filled and easy to clean, located in a location that is reachable by solid waste transport vehicles. Then, empty and clean at least 1 x 24 hours (RI Minister of Health No.1204 / Menkes / SK / X / 2004).

For waste transportation, the transportation of domestic solid waste from each room to a temporary shelter in Pare Regional Hospital of Kediri Regency uses closed trolleys where the number of hospital trolies currently has 4 wheels and 4 wheels 2 . Waste bags are collected and separated according to their color code. Non-clinical part waste, for example, is taken to the compactor; clinical part waste is brought to the incinerator. Transportation with special vehicles because there is cooperation with the Department of Sanitation and Parks (DKP) vehicles used to transport the waste should be emptied and cleaned every day, if necessary (for example if there is a leakage of waste bags) cleaned using chlorine solution.

d. Dimensions of elimination of non-medical solid waste in Pare Regional Hospital, Kediri Regency,

After being used with a compactor, non-clinical waste can be disposed of in landfill sites, clinical waste must be incinerated, if not possible it must be buried with lime and planted kitchen waste should be disposed of on the same day so it does not rot. Then regarding the waste gas, the management effort is simpler than the liquid waste, the management of gas waste cannot be separated from the efforts of sanitary rooms and buildings, especially in maintaining indoor air quality which among others is required that (Agustiani et al, 2000): No smell ( terutania by H2S gas and Anioniak); Dust levels do not exceed $150 \mathrm{Ug} / \mathrm{m} 3$ in an average measurement for 24 hours. Number of bacteria. Operating room: less and 350 calories / $\mathrm{m} 3$ of air and germ-free diogens (especially alpha streptococcus haemoliticus) and gas gangrer spores. Treatment and isolation rooms: less and 700 kalorilm3 air and free of pathogenic germs. The level of gas and hazardous substances in the air does not exceed the maximum concentration that has been determined.

Pare District Hospital of Kediri has a medium / medium sized incinerator that can burn at temperatures of $1300-1500{ }^{\circ} \mathrm{C}$ or higher and may be able to recycle up to $60 \%$ of heat generated for hospital energy needs, specifically for non-medical solid waste or organic waste (garbage households) do not go through a process with an insinertor but after being sorted out, a TPS (temporary shelter) is put into the hospital which is then transported daily by the Sanitation and Parks Office (DKP) official to the Sanitation and Parks Office to be transported to the landfill (final disposal site) in the waste Sekoto village, Pare sub-district, Kediri Regency, which is the center of landfill waste. A hospital can also obtain additional income by serving incineration of hospital waste originating 
from other hospitals. A good modern incinerator certainly has several advantages including its ability to accommodate clinical and non-clinical waste, including sharp objects and unused pharmaceutical products (Rostiyanti and Sulaiman, 2001). If incineration facilities are not available, clinical waste can be stockpiled with lime and planted. Liming steps (liming) include the following (Djoko, 2001): Digging a hole, with a depth of about 2.5 meters, spread clinical waste at the bottom of the hole to as high as $75 \mathrm{~cm}$, add a layer of lime. A layer of waste which is covered by a layer of lime can still be added up to a height of 0.5 meters below ground level. Finally, the hole must be covered with soil.

e. Dimensions of non-medical solid waste utilization into compost in Pare District Hospital, Kediri,

Non-medical solid waste in Pare Regional Hospital of Kediri Regency has a big opportunity to be used as compost. Solid Waste Treatment is an effort to reduce the volume, change the shape or destroy the solid waste carried out at the source. Waste that can still be utilized should be reused for organic solid waste can be processed into compost that can be used to fertilize plant vegetation in the hospital.

Patient comfort as measured in the dimensions of beauty, air odor and air temperature in the Pare Regional Hospital of Kediri Regency is a comprehensive assessment of a person's environment. Humans judge their environment based on stimulation that enters themselves through the six senses through the nerves and digested by the brain to be assessed. In this case, it involves not only physical biological problems but also feelings. Sound, light, smell, temperature and other stimuli are captured at once, then processed by the brain. Then the brain will provide a relative assessment of whether the condition is comfortable or not. Discomfort in one factor can be covered by another factor (Sakwiko, 2009). Reality comfort is not only enjoyed by hospital patients but also those who feel comfort due to waste management as well as visitors, hospital management themselves starting from the level of cleaning staff, administrative staff, nurses, doctors and leadership levels. If the hospital conditions are comfortable, of course psychologically it will accelerate the level of healing for patients due to the beautiful healing garden (garden for rest), fresh air, the absence of environmental pollution and no humidity air temperature. For visitors will be an effective means of promotion because visitors after feeling comfortable will of course tell the public at large. For cleaning staff is a work performance and at the same time a separate satisfaction, while for employees, nurses, doctors and leaders in addition to making prestige / pride will also encourage improving their respective performance. From the description above it can be said, that the comfort in Pare Regional Hospital of Kediri Regency must be felt not only by residents, managers and visitors but also by the wider community because it is a necessity.

Environmental comfort is a significant predictive factor in determining satisfaction with a hospital condition (RS) in addition to clinical services (Harris et al., 2002). Kolcaba et al. (2006) also stated that through environmental changes in supporting hospital comfort had a positive impact on employee performance and improved patient and visitor comfort while in the hospital. The comfort dimensions include,

a. Dimensions of environmental beauty in Pare Regional Hospital, Kediri Regency,

According to Arianti (2013), people are increasingly aware to provide green open spaces as a means and infrastructure to improve the quality of the environment properly. This green space can be in the form of an open area in the form of an elongated area / lane and / or grouped, the use of which is more open, a place to grow plants, both those that grow naturally and are intentionally planted. The park in Pare Regional Hospital is also expected to become one of the green open spaces that can improve the comfort of patients, visitors and staff of Pare Regional Hospital. Even though there is a target to become a Green Hospital, Pare Regional Hospital is still in the development of the management of the management and treatment of park vegetation as a green open space. 
b. Dimensions of the smell of air in the neighborhood of Pare Regional Hospital, Kediri Regency,

Humidity is a significant factor affecting the air around Pare Regional Hospital, Kediri Regency. The relative temperature and humidity of air also has an effect on humans in terms of the comfort and average resistance of a person to heat stress. Toronto Public Health Department (2013), temperature and humidity are two important factors that influence a person's comfort on the effects of weather, especially in summer. This shows that there is a need for further management of the green open space of Pare Regional Hospital of Kediri Regency which is expected to help reduce the level of thermal discomfort.

c. Dimensions of temperature / humidity in the environment Pare District Hospital, Kediri,

The air temperature in Pare Regional Hospital of Kediri Regency has a certain pattern in its daily life. The air temperature in each unit increases during the day and again decreases in the afternoon. On the contrary, the relative humidity of the air in Pare Regional Hospital at each location unit is high in the morning and then decreases in the afternoon and again rises in the afternoon. According to Adi (2004) temperature and humidity affect nosocomial infections that occur in hospitals, as an example in his research is Banyumas Regional Hospital. Both of these factors provide a real correlation to the number of germs in the air. The results of the calculation of the thermal discomfort index indicate that the temperature and relative humidity of the air in Pare Regional Hospital provide a sensation of discomfort that is strong to very strong (41-46). This indicates that there is still a need for better management in the management and maintenance of parks or green open spaces in Pare Regional Hospital, especially on tree vegetation that can provide shade that can reduce thermal discomfort.

The results of the study prove that, improving non-medical waste management can increase patient satisfaction as measured in the dimensions of performance, reliability, conformity to specifications, durability, service abilities, aesthetics and perceived quality. This shows that, if non-medical waste management is carried out as a fixed procedure (procedure) regarding the management of non-medical waste provided by the Pare Regional Hospital of Kediri Regency, both patients and visitors will be satisfied.

Patient satisfaction in Pare Regional Hospital, Kediri, is related to the comparison between expectations and reality, that is, if the expectations or needs are the same as the services provided, the patient will feel satisfied. If the services provided to patients are lacking or not in accordance with the needs or expectations of the patient, the patient becomes dissatisfied. Patient satisfaction is a comparison between the expectations held by patients with the reality received by patients with the reality received by patients with the reality received by patients when consuming products or services, Indarjati (2001). From the description above, satisfaction for patients must be given by the Pare Regional Hospital of Kediri Regency because it will have a negative impact on the survival of the hospital.

A patient's positive experience of a product is shaped by satisfaction, where the product consumed is equal to or exceeds consumer expectations. Therefore Yi (1990) states that satisfaction is the result of a comparison between the perceived product performance with expectations for the product's performance. Zineldin (200) has a more or less the same view that satisfaction is the overall attitude of the patient towards the service provider or an emotional reaction to the difference between what is anticipated (expected) and felt by the patient. Klaus (1985) confirms the above opinions by stating that satisfaction is the patient's subjective evaluation of a consumer experience, based on several relationships between patient perceptions and objective attributes of the product. Furthermore, Kotler (2000) states that patient satisfaction is a feeling of pleasure or disappointment someone who appears after comparing the perceived product performance with expectations. Engel et al. (2004) state that patient satisfaction is a postpurchase evaluation in which the alternative chosen is equal or exceeds patient expectations. Various opinions about satisfaction above conclude two things, namely the expectation of what 
will be consumed and the perceived results of the products consumed. If the expectation is higher than the results or perceived product performance will result in dissatisfaction. Conversely, if the expectation is lower than the perceived result will cause satisfaction. In this context, the company's task is to strive for products and services produced to have a performance that is higher than consumer expectations. High performance products and services perceived by consumers are seen as quality products and services.

The quality of solid waste management in the Pare Regional General Hospital of Kediri Regency can be used as an indicator in evaluating patient satisfaction and dissatisfaction with the facilities or services offered. Quality in marketing strategy is an important variable both for companies engaged in the goods and services industry. Companies can use quality as a weapon in the "war" against competitors. Companies that produce goods or services of higher quality than competitors. More able to survive in competition. So it can be said that the competitive advantage of a company is determined by the quality of its products and services. Besides quality is important for companies, quality is also important for consumers. Consumers generally choose products that are believed to have quality in accordance with the sacrifice he made. That is, in purchasing decisions, consumers consider product quality by comparing quality with product prices. Furthermore, to find out more clearly, the dimensions of patient satisfaction in Pare District Hospital in Kediri are as follows,

a. Dimensions of performance / performance in the hospital,

The performance dimension at the Hospital shows how the speed and ease of the Pare Regional Hospital of Kediri Regency in handling waste in creating a clean and healthy environment.

b. Dimensions of reliability or reliability in hospitals,

The reliability dimension in the hospital is how the waste management staff in working to manage the waste in Pare Regional Hospital of Kediri Regency is environmentally friendly. It is likely to experience dissatisfaction or incompatibility with expectations for the services provided. This is influenced by the ability possessed by cleaning staff in providing solid waste management services that is with the ability and good experience to provide cleaning services at home Pare District Hospital, Kediri.

c. Dimensions of conformance with specifications / conformance to specifications at the hospital,

Dimensions of conformance with specifications or conformance to specifications at the hospital that is the extent to which the handling characteristics of the Pare Regional Hospital waste Kediri meet the standards that have been predetermined such as safety standards and emissions are met such as non-medical solid waste cleaning equipment in accordance with the concept of green hospital.

d. Dimensions of durability or durability in the hospital,

Dimensions of durability or durability in the hospital is how the condition and quality of the equipment used in waste management in Pare Regional Hospital of Kediri Regency is related to some time the product is used. This dimension includes the technical age and economic age in the use of hospital equipment which includes containers / containers of Pare Regional Hospital of Kediri Regency

e. The dimension of service ability in hospitals,

The dimensions of service ability in hospitals are speed, competence, and satisfying handling of waste complaints provided by cleaning staff in Pare Regional Hospital, Kediri Regency at any time.

f. The aesthetic dimension in the hospital,

The aesthetic dimension in the hospital is the attractiveness of the hospital that can be captured by the five senses in terms of waste management in Pare Regional Hospital, Kediri, namely the hospitality of the officers, complete and modern hospital equipment, hospital architecture design, room decoration, comfort of the waiting room, beautiful garden and cool, and so on.

g. Dimensions perceived or perceived quality in hospitals, 
Dimensions perceived or perceived quality include the image and reputation and responsibilities at the hospital, namely how the impression received by patients on the achievements and excellence of Pare Regional Hospital in Kediri compared to other hospitals and the hospital's responsibility during the process of managing solid waste both from incoming and outgoing patients. the hospital is in good health.

\section{Conclusions}

Management of non-medical solid waste and hospital garden vegetation has not been carried out optimally. Improved management of non-medical waste will increase patient comfort and satisfaction. The high level of comfort in the patient will increase patient satisfaction. Good management of non-medical waste does not directly affect satisfaction but through patient comfort and Vegitation in the hospital garden influences patient comfort and satisfaction

\section{Acknowledgement}

Authors would like thank to Director of Pare Regional Hospital of Kediri Regency who has given the author an opportunity to conduct research. No authors is in conflict.

\section{References}

Agustiani E., Slamet A., Rahayu D.W. 2000. Penambahan Powdered Activated Carbon (PAC) Pada Proses Lumpur Aktif untuk Pengolahan Air Limbah Rumah Sakit. Majalah IPTEK: Jurnal Ilmu Pengetahuan Alam dan Teknologi. 11 (1), pp. 30-38.

Akers, 1993. Paperboard Hospital Waste Container. United States Patent. 5, 240, 176.

Arianti, I. 2013. Ruang Terbuka Hijau. Retrieved from: http://repository.polnep.ac.id/xmlui/ handle/123456789/96. (accessed 29 Mei 2013).

Arikunto. 2006. Prosedur Penelitian Suatu Pendekatan Praktek. Jakarta : Rhiseta Cipta.

Atik, AMA. 2011. Evaluation of Integrated Solid Waste Management in Roemani Hospital,

Semarang. Master Thesis. Magister of Environmental Science. Diponegoro University. Semarang.

Bentler, P. M dan Chou, C. P. 1993. Some New Covariance Structure Model, in K. A. Bollen dan J. Scott Long (Editors). Testing Structural Equation Model. Sage Publication.

Browne dan Cudek, 1993. Alternative Ways of Assessing Model Fit, in K.A. Bollen dan J.Scott Long (Editors). Testing Structural Equation Model. Sage Publication.

Chin, W. and Todd, P. 1995. On the Use, Usefulness, and Ease of Use of Structural Equation Modeling in MIS Research: A Note of Caution. MIS Quarterly. 9(2), pp. 237-246.

Djoko, S. 2001. Pengelolaan Limbah Rumah Sakit. Sipil Soepra: Jurnal Sipil. 3(8), pp. 91-99.

Harris N, Pisa L, Talioga S, Vezeau T. 2009. Hospital going green: a holistic view of the issue and the critical role of the nurse leader. Holist. Nurs. Pract. 23(2), pp. 101-111.

Harris PB, McBride G, Ross C, Curtis L. 2002. A Place to Heal: Environmental Sources of Satisfaction among Hospital Patients. Journal of Applied Social Psychology. 32(6), pp. 1276-1299.

Kolcaba K, Tilton C, Drouin C. 2006. Comfort Theory: A Unifying Framework to Enhance The Practice Environment. Journal of Nursing Administration. 36 (11), pp. 538.

Malhotra, N.K. 2004. Marketing Research: An Appliied Orientation, $4^{\text {th }}$, translated by Maryam, R.S. Riset Pemasaran: Pendekatan Terapan, Penerbit Indeks. Jakarta.

Maruyama, G and Mc, Bill. 1980. Evaluating Causal Models: An Application of MaximumLikelihood of Structural Equations. Psychological Bulletin. 87(3), pp. 502-512. 
Sattler B, Hall K. 2007. Healthy Choices: Transforming Our Hospitals into Environmentally

Healthy and Safe Places. OJIN: The Online Journal of Issues in Nursing. 12(2), DOI: $10.3912 /$ OJIN.Vol12No02Man03.

Satwiko, Prasasto. 2009. Fisika Bangunan. Andi. Yogyakarta.

Sundana EJ. 2000. Hospital Waste Minimization in Indonesia Case Studies: Muhammadiyah Bandung General Hospital (RSMB). Jurnal Itenas. 4(1), pp. 43-49.

Toronto Public Health Department. 2013. Summer Safety: How to Beat the Heat. Retrieved from: http://www.gov.ns.ca/hpp/publications/HeatSummerSafety.pdf. (accessed 30 May 2013).

Wilburn S. 2007. Overview and Summary: Environmental Health: Important Choices for a Greener World. OJIN: The Online Journal of Issues in Nursing, 12(2). DOI: $10.3912 /$ JJIN.Vol12No02ManOS. 
(This page is intentionally blank) 